\title{
Blended Learning Researches in Iran: Several Fundamental Criticisms
}

\author{
Farhad Seraji \\ fseraji@basu.ac.ir \\ Department of education, Bu- Ali Sina University, Hamedan, Iran

\section{Muhammad Attaran} \\ attaran_m@yahoo.com \\ department of curriculum Studies, University of Kharazmi, Tehran, Iran
}

\section{Seyyed Mohsen Azizi}

smohsenazizi@yahoo.com

Clinical Research Development Center of Imam Reza Hospital

Kermanshah University of Medical Sciences, Kermanshah, Iran

\begin{abstract}
The present study seeks to critically review the state of the blended learning researches in the Iranian context. For this critique, 47 papers about blended learning were found in a number of indexing databases and their contents were analyzed. The contents mainly revolved around use of relevant terminology, features of blended learning, methodology, levels of blended learning, variables of the study, and the analyzed educational programs. Some major criticisms that can be leveled at these studies include limited range of terminology, inappropriate use of key concepts, overemphasis on quantitative methods, overuse of pseudo-empirical method, lack of case studies, mistaking blended learning for application of computers in education, excessive concentration on the level of educational programs, superficial treatment of the distinction between learning and retaining, lack of attention to some of the variables of blended learning, and use of blended learning for primary and secondary education.
\end{abstract}

\section{Keywords}

Blended learning; Research; Criticisms; Terminology; Methodology; Blended levels 


\section{Introduction}

When merely online learning environments which had come with the tremendous advancement of information and communication technology (ICT) did not stand the test of time, educational policymakers and practitioners tended to adopt the advantages and integrate them into physical environments to create blended learning environments. This new type of environment facilitates access, enhances interaction among learners, reduces costs, improves learning quality, and encourages active learning, self-learning, as well as learning flexibility (Cuesta, 2018; Gedik, Kiraz, \& Ozden, 2013). The notion of blended environments, which was dubbed as "the new tradition of higher education" by Rose and Gage (2006), was invented in 2000 as the third wave of learning environments.

Although implementation of technology in physical learning environments and combination of various learning methods have been common throughout the history of learning technologies, blended environments are essentially intended to combine the core characteristics of both physical and virtual environments to make strategic use of teaching methods and activities as well as learning theories with aim of fulfilling learning objectives. How and to what extent the tools, features, methods, and theories should be combined are two challenging questions that problematize any approach to the issue of blended learning.

Various conceptions, as well as the immensity of blended learning, make this notion more difficult to deal with. Oliver \& Trigwell (2005) use the terms blended teaching and learning with blended pedagogies instead of blended learning and emphasize that in every educational environment teaching activities that facilitate learning are done before the actual learning takes place. Some authors take the term "hybrid learning" to refer to educational programs in which part of the time is spent on physical learning while the rest of the time is dedicated to online activities such as transfer of information, exchange of ideas, delivery of projects, doing assignments, and participation in assessments (Sands, 2002; Johansson, Abia, \& Quest,2016, p. 94; Arispe \& Blake, 2012; Antonoglou, Charistos \& Sigalas, 2011). In some texts, terms like "dual-mode university" and "brick-and-click university" are used as equivalents to blended learning, thereby emphasizing that part of activities including content presentation and access to resources are done online while the other part which consists of registration, contact with instructors and other students (Bleed, 2001), and participation in assessments are done in a physical manner (Turner \& Crews, 2005). Hyflex learning is another term which refers to combination of physical and virtual features, methods and pedagogies to respond to learners' needs, and customization of the learning environment (Kyei-Blankson \& Godwyll, 2010; Ochoa, Hyde, Curtois, Vazquez-Rodriguez, Walker, Gendreau,\& Burke (2012,). Purposeful learning also refers to combination of tools, methods, and technologies in line with the fulfillment of educational aims (Picciano, 2009) Multimodal learning is another term used to denote a teacher's innovative combination of different technologies such as CD, SMS, applications, slide presentations, podcasts, and email to involve students in educational issues outside the classroom (Stoffberg \& Blignaut, 2008). Finally, rotational and reversed models of learning deal with a combination of physical and virtual learning environments in which the educational content is presented to the learner before the class through some form of technology so that the time of the class could be used for further explanation and applications of the educational content (Johansson \& Daugherty, 2008).

The second group of attempts to delimit the notion of blended learning offer a cline-like view of the combined physical and virtual environments. In this regard, The Sloan Consortium (2007) defines a blended learning program as a program in which between 20 percent and 79 percent of the content is delivered online. Allen and Seaman (2007) classify educational programs into four types 
according to their use of ICT: traditional (without technology), web-facilitated (with students recovering and studying textual and multimedia material on their own), hybrid/blended, and online.

Margulieux, Bujak, McCracken \& Majerich (2014) distinguish blended learning environments based on place of education, medium of presentation, type of education, and synchronicity. Place refers to whether the learner receives instruction in a classroom or online. Medium denotes whether lessons are delivered by a person or through technology? Type of education makes a distinction between content-based and activity-based types of education. Finally, synchronicity refers to the degree to which the individual or cohort pace of progress is facilitated.

The third group of research focuses on the implications of blended environments. Carman (2005) points out that combination physical and virtual learning environments can result in five elements, namely, live events, flexible and self-pace learning, participation, assessment, and constant support $(p, 2)$. The more remarkable these elements, the closer the environment is to the conditions of blended learning. According to Boelens, Wever \& Voet (2017), the four indicators of blended learning environments are flexibility of the program, encouragement of interaction, facilitation of the learning process, and creation of an atmosphere of active learning. Flexibility can be measured by the flexibility of time, place, method, and learning pace. Flexibility of time refers to the integration of synchronous and asynchronous features of physical and virtual environments into the blended environment. Flexibility of place refers to using the potential of physical place and, at the same time, eliminating distance-related issues by making use of virtual features. Flexibility of method refers to both teacher's and learner's use of various methods in the process of education. Finally, flexibility of learning pace refers to the range of the learner's opportunities to determine their pace of learning. Synchronous and asynchronous forms of communication in cyberspace are likely to extend the psychological and communicative space while actually deteriorating the quality of communications and, leading to distance in interactions (Moore \& Kearsley, 2011). In a blended environment, however, part of communications takes place in a synchronous, physical manner the other part take place online in a synchronous or asynchronous manner, thereby contributing to enhancement of interactions by developing initial acquaintance and creating a friendly atmosphere. The third indicator of blended learning consists of facilitating the learning process through contributing to learners' self-regulation and engaging them in organization, time management, improvement of self-efficacy, presentation of various learning activities, and use of technology to support learning. This environment helps the learner with aim-setting, planning, supervision, modification, and assessment in the process of learning. The third indicator of this environment is to contribute to development of psychological security, improve internal motivation, engender cognitive involvement, provide assessment opportunities, and offer real learning situations.

Finally, the fourth group of research into blended learning revolves around policies, strategies, coordination, and support. From this perspective, Graham, Woodfield, \& Harrison (2013) emphasize that for recognition of the state of the development of blended learning in educational organizations we should first examine the required strategies, structure, and support. According to Moskal, Dziuban \& Hartman(2013), setting general and specific aims, coordination among different units of an educational organization, establishment of a common language among beneficiaries, professional development of teachers, development of a suitable curriculum, support of teachers and learners, provision of reliable facilities, creation of a database for the university or institution, making detailed policies, and devising an efficient financial model are some of the prerequisites for blended learning. Also, Moskal et al (2013) focuses on human resources as well as structural, symbolic, and political aspects. From their point of view, major issues to be considered with regard to blended learning include determining the method of providing the required technology, defining the notion of blended learning, proposing a strategic plan, developing a time schedule, preparation of the structure of a curriculum assessment system and a blended learning curriculum, developing a support system for the technical and pedagogical fields of human resources, adopting necessary 
measures for preparing teachers and learners to be adapted to innovative changes from a symbolic point of view, and preparing the organization for changes as well as reducing its resistance from a political point of view. In a blended learning environment, therefore, interaction, access to information in the form of self-study or multimedia content, access to learning sources, participation, opportunities for questioning and reflection, and learner-oriented teaching strategies are done through policies, strategies, support, technology, and coordination among other resources. The most important features of a blended learning environment are summarized in Table 1.

\begin{tabular}{|c|c|c|}
\hline Stages & & Elements and features \\
\hline $\begin{array}{l}\text { Policy-making } \\
\text { and planning }\end{array}$ & $\begin{array}{l}\text { Policy-making: Dete } \\
\text { the advantages of } \\
\text { realizing active lear } \\
\text { the level of organiza }\end{array}$ & $\begin{array}{l}\text { rmining the policies of the educational organization to blend } \\
\text { hysical and virtual learning environments with the aim of } \\
\text { ing and responding to the learning needs of individuals at } \\
\text { tion, curriculum, program, and activity. }\end{array}$ \\
\hline & $\begin{array}{l}\text { Planning: developin } \\
\text { strategies for impler }\end{array}$ & $\begin{array}{l}\text { an operational and executive plan by adopting appropriate } \\
\text { enting blended learning at different levels. }\end{array}$ \\
\hline & $\begin{array}{l}\text { Schedule: Preparing } \\
\text { allocating the nece } \\
\text { environment. }\end{array}$ & $\begin{array}{l}\text { a time plan for using physical and virtual environments and } \\
\text { ssary time to each program in the physical and virtual }\end{array}$ \\
\hline & $\begin{array}{l}\text { Support: Financial, } \\
\text { during the program. }\end{array}$ & echnical, and educational support of teachers and learners \\
\hline & $\begin{array}{l}\text { Coordination: } \mathrm{Coc} \\
\text { educational, and res }\end{array}$ & $\begin{array}{l}\text { rdination among administrative, financial, technical, } \\
\text { earch units. }\end{array}$ \\
\hline \multirow[t]{9}{*}{ Implementation } & \multirow{4}{*}{$\begin{array}{l}\text { Flexibility of } \\
\text { educational } \\
\text { program }\end{array}$} & $\begin{array}{l}\text { Time: Synchronous physical and virtual programs; } \\
\text { asynchronous virtual programs. }\end{array}$ \\
\hline & & Place: Physical and virtual programs. \\
\hline & & $\begin{array}{l}\text { Learning method: Offering various teaching methods by the } \\
\text { teacher and optional selection of learning methods by the } \\
\text { learner. }\end{array}$ \\
\hline & & $\begin{array}{l}\text { Pace of learning: Selection of method, duration, and pace } \\
\text { of learning according to the characteristics of the learner. }\end{array}$ \\
\hline & \multirow{2}{*}{$\begin{array}{l}\text { stimulating } \\
\text { interaction }\end{array}$} & $\begin{array}{l}\text { Synchronous interaction: Synchronous physical interaction } \\
\text { for initial acquaintance; elimination of conflicts; analysis of } \\
\text { multilayered issues. }\end{array}$ \\
\hline & & 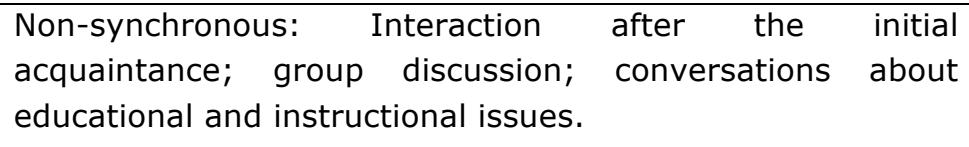 \\
\hline & \multirow{3}{*}{$\begin{array}{l}\text { Encouragement of } \\
\text { active learning }\end{array}$} & Enhancement of internal motivation \\
\hline & & Cognitive involvement with lessons \\
\hline & & Reflection on one's own learning process \\
\hline
\end{tabular}




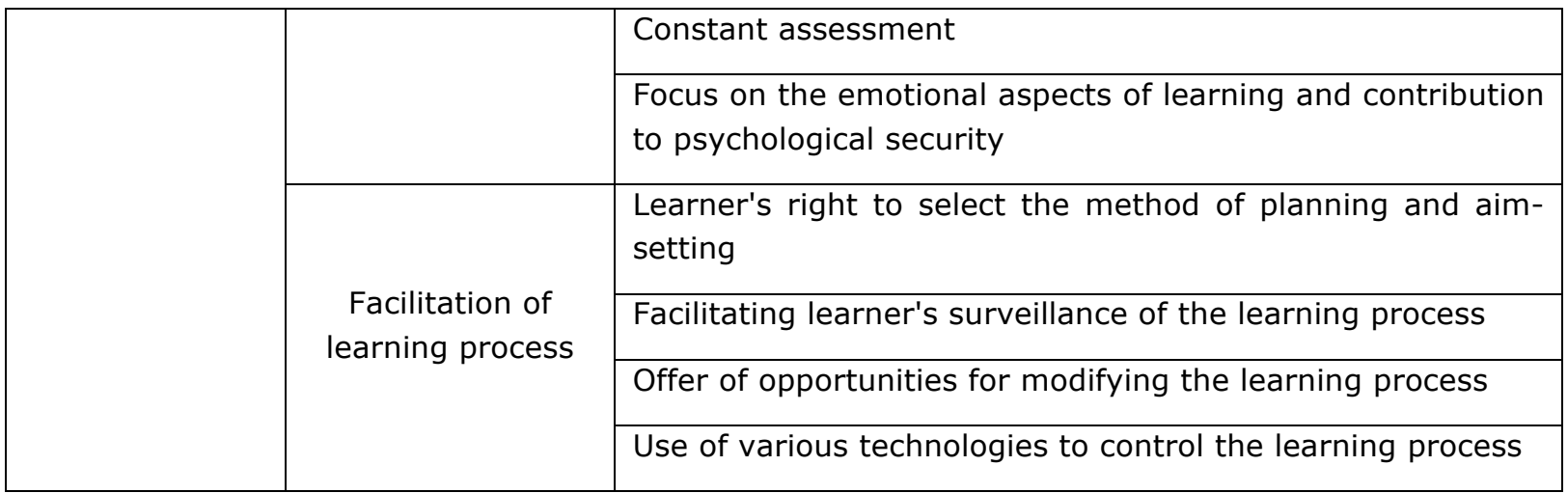

Table 1 . Summary of the features of blended learning

\section{a. Main Focus of Research}

In fact, blended learning process is collaborative accumulation of pedagogies and technologies to improve the quality of learning and realize educational aims. A blended learning environment is composed of educational methods, tools, and technologies of both physical and virtual environments as required by learners' needs. The variety of definitions and conceptions, however, may challenge the researchers in the field. According to their understanding of the issues of a scientific field, researchers define and investigate certain variables with certain methods. Moreover, they try to predict new situations to identify problems, collect and analyze the data, and arrive at conclusions. General conceptions of a field and its major issues may affect the problem in question, selection of variables, research methodology, and development of the central concept. Boelens, De Wever \& Voet (2017) states that the major challenges of blended learning research include limiting its features to combination of physical and virtual environments and lack of attention to important features such as flexibility of the program, facilitation of education interaction, facilitation of learning process, and creation of an active learning atmosphere. Therefore, the main purpose of this study is analyzing and critiquing of blended learning researches.

\section{Research Goal and questions}

The main goal of this research is to critique blended learning researches in Iranian context. To accomplish this goal, two questions can be formulated as following:

RQ1: What is status of blended learning researches in Iranian context?

RQ2: How has blended learning researches been criticize in the Iranian context?

\section{Research Methodology}

The method followed in this paper is critical review of studies. Critical review consists of five interdependent steps, namely, study and understanding, comparison, analysis, assessment and conceptual categorization. In the initial step of the present study, Persian indexing databases such as SID, Magiran, and Noormags and international databases like Google Scholar, Scopus, Science Direct, Wiley, and Doaj were searched with a number of Persian and English keywords in the field of blended learning and instruction (blended learning, blended instruction, integrated learning, integrated instruction). 47 papers published in English and Persian was found. Then each paper 
underwent content analysis for at least three times by two reviewers with regard to the sections of problem statement, aims, framework of the study, variables, sample, data collection, method of analysis, and interpretation of the results. Six major areas were determined for the content analysis of the papers: application of the terminology of blended learning, dominant methodology, discussion of the features of blended learning, levels of blended learning, variables of the study, and the educational programs in question. Each paper was first given to both reviewers and, in case of any disagreement between the reviewers; it was given to a third reviewer. Whichever analysis conformed to the opinion of the third reviewer was selected as the final analysis. The trends of the studies were discovered by calculating frequency percentages and means and the final reviews were presented in the form of eleven parts based on the six categories mentioned above.

\section{Results}

\begin{tabular}{|c|c|c|c|}
\hline & Title & Authors & Journals \\
\hline 1 & $\begin{array}{l}\text { The study of blended Teaching Methods on } \\
\text { Learning, Motivation and Interest in Learning } \\
\text { Anatomy Course in Medical Students. }\end{array}$ & F. Zarabian & $\begin{array}{l}\text { Research in Medical } \\
\text { Education, 2018, 10(1), } \\
63-71\end{array}$ \\
\hline 2 & $\begin{array}{l}\text { The effect of Blended instruction on learner } \\
\text { success and satisfaction in vocational } \\
\text { education system }\end{array}$ & $\begin{array}{l}\text { M. Mouhammai., } \\
\text { R. Marzoogie., } \\
\text { G.Salimi \& } \\
\text { S.Mansoori }\end{array}$ & $\begin{array}{l}\text { Journal of Learning and } \\
\text { Instruction Studies, 2017, } \\
9(1), 91-108 .\end{array}$ \\
\hline 3 & $\begin{array}{l}\text { The Effect of Blended Instruction on Students } \\
\text { Mathematics Learning }\end{array}$ & $\begin{array}{l}\text { E.Zaraii Zavarki } \\
\text { \& E. } \\
\text { Toofaninejad }\end{array}$ & $\begin{array}{l}\text { Journal of educational new } \\
\text { thoughts, 2017,13(1), 73- } \\
90 .\end{array}$ \\
\hline 4 & $\begin{array}{l}\text { The effect of blended learning on EFL learners' } \\
\text { reading proficiency. }\end{array}$ & $\begin{array}{l}\text { T.Ghazizadeh \& } \\
\text { H. Fatemipour }\end{array}$ & $\begin{array}{l}\text { Journal of Language } \\
\text { Teaching and } \\
\text { Research,2017, 8(3), 606- } \\
614 .\end{array}$ \\
\hline 5 & $\begin{array}{l}\text { The Effect of Flipped Model of Instruction on } \\
\text { EFL Learners' Reading Comprehension: } \\
\text { Learners' Attitudes in Focus }\end{array}$ & $\begin{array}{l}\text { M. Karimi \& R. } \\
\text { Hamzavi }\end{array}$ & $\begin{array}{l}\text { Advances in Language and } \\
\text { Literary } \\
\text { Studies,2017, 8(1), 95- } \\
103 .\end{array}$ \\
\hline 6 & $\begin{array}{l}\text { The Effect of designed content based on every } \\
\text { Gardner's Multiple Intelligences in interactive } \\
\text { gamut on students learning in conservatory } \\
\text { school in compound education }\end{array}$ & $\begin{array}{l}\text { E. Badiee \& M. } \\
\text { Farajollah }\end{array}$ & $\begin{array}{l}\text { Journal of Research in } \\
\text { Curriculum Planning,2016, } \\
13(2), 13-22\end{array}$ \\
\hline 7 & $\begin{array}{l}\text { The effect of Blended Method of Teaching on } \\
\text { Output of learning Quran Among Honor High } \\
\text { school students. }\end{array}$ & $\begin{array}{l}\text { E. Fathiazar., T. } \\
\text { H ashemi., Y. } \\
\text { Adib., S. Vahedi } \\
\text { \& M. Tabatabie. }\end{array}$ & $\begin{array}{l}\text { Quarterly Journal Of } \\
\text { Education, 2016, 32(3), } \\
\text { 131-153. }\end{array}$ \\
\hline 8 & $\begin{array}{l}\text { Effectiveness of Social networked Base } \\
\text { Blended Learning on girl students self- }\end{array}$ & $\begin{array}{l}\text { F. Shahrokhi., H. } \\
\text { Eivazi., A. }\end{array}$ & Journal of Social Research, \\
\hline
\end{tabular}




\begin{tabular}{|c|c|c|c|}
\hline & regulation in Karaj & $\begin{array}{l}\text { Babakhonloo \& } \\
\text { B. Shogi }\end{array}$ & $2016,9(4), 71-84$ \\
\hline 9 & $\begin{array}{l}\text { Analysis of the effect of conventional and } \\
\text { combination taught Methods on Learning and } \\
\text { Retention level }\end{array}$ & $\begin{array}{l}\text { R. Emadi, \& N. } \\
\text { Zanjan Maskan }\end{array}$ & $\begin{array}{l}\text { Journal of Technology } \\
\text { education }\end{array}$ \\
\hline 10 & $\begin{array}{l}\text { Blended learning as a flexible approach to } \\
\text { developing in-service training model for } \\
\text { Iranian teachers in field of science and } \\
\text { nanotechnology. }\end{array}$ & Z. Mehreban & $\begin{array}{l}\text { Journal of Educational } \\
\text { Innovations,2016, 15(3), } \\
57-84 \text {. }\end{array}$ \\
\hline 11 & $\begin{array}{l}\text { A study on the impact of MALL (Mobile Assisted } \\
\text { Language Learning) on EFL learners' reading } \\
\text { comprehension. }\end{array}$ & $\begin{array}{l}\text { L. Khubyari \& } \\
\text { M.H. Narafshan }\end{array}$ & $\begin{array}{l}\text { International Journal of } \\
\text { English Language } \\
\text { Teaching,2016, 4(2), 58- } \\
69 .\end{array}$ \\
\hline 12 & $\begin{array}{l}\text { Flipped Learning in higher education: } \\
\text { Narratives of a teacher. }\end{array}$ & $\begin{array}{l}\text { Z. Golzari \& M. } \\
\text { Attaran }\end{array}$ & $\begin{array}{l}\text { Journal of Curriculum } \\
\text { Studies Theory and } \\
\text { Practice, } 2016,4(7): 81- \\
136\end{array}$ \\
\hline 13 & $\begin{array}{l}\text { Comparison of virtual, traditional and blended } \\
\text { model in English learning with special goal in } \\
\text { medical and pharmaceutical students. }\end{array}$ & $\begin{array}{l}\text { O. Sohili., G. } \\
\text { Karimkhanloie } \\
\text { \&M. Ahadian }\end{array}$ & $\begin{array}{l}\text { Journal of Instruction } \\
\text { Development in Medical } \\
\text { Science, } 2016,9(3), 53- \\
60 .\end{array}$ \\
\hline 14 & $\begin{array}{l}\text { Comparison of virtual, traditional and blended } \\
\text { model in English learning with special goal in } \\
\text { medical and pharmaceutical students. }\end{array}$ & $\begin{array}{l}\text { O. Sohili., G. } \\
\text { Karimkhanloie } \\
\text { \&M. Ahadian }\end{array}$ & $\begin{array}{l}\text { Journal of instruction } \\
\text { development in medical } \\
\text { science, } 2016,9(3), 53-60\end{array}$ \\
\hline 15 & $\begin{array}{l}\text { The Combination of Conventional Teaching } \\
\text { Methods its Effect on Student Academic } \\
\text { Engagement }\end{array}$ & $\begin{array}{l}\text { R. Emadi \& } \\
\text { N.Ahokhash }\end{array}$ & $\begin{array}{l}\text { Journal of Cognitive } \\
\text { Strategies in Learning } \\
2015,3(1) 58-74 \text {. }\end{array}$ \\
\hline 16 & $\begin{array}{l}\text { The Effect of Blended learning-Based Social } \\
\text { Networks on Second Year High School } \\
\text { Students' Self-efficacy in Math }\end{array}$ & $\begin{array}{l}\text { M. Movahedi., } \\
\text { M. Esmaeilifar \& } \\
\text { N. Gholamipour }\end{array}$ & $\begin{array}{l}\text { Journal of technology in } \\
\text { instruction and learning, } \\
2015,3(1), 7-22\end{array}$ \\
\hline 17 & $\begin{array}{l}\text { Survey on Faculty Members Viewpoint in } \\
\text { Payame -Noor University to the Blended } \\
\text { Learning Approach Based on Individual } \\
\text { Variables and Computer Skill Level. }\end{array}$ & A.Ajam & $\begin{array}{l}\text { Journal of Teaching and } \\
\text { Learning Researches, } \\
2015,2(6), 210-195 \text {. }\end{array}$ \\
\hline 18 & $\begin{array}{l}\text { Effectiveness of Blended Learning on Critical } \\
\text { Thinking Skills of Nurse Students, }\end{array}$ & $\begin{array}{l}\text { B. Hajrezayi., H. } \\
\text { Rosshani } \\
\text { Alibinasi., M. } \\
\text { Shahalizade., M. } \\
\text { Zeynali \& M. } \\
\text { Badali }\end{array}$ & $\begin{array}{l}\text { Journal of Nurse Education, } \\
2015,4(1), 49-59 .\end{array}$ \\
\hline 19 & $\begin{array}{l}\text { Teaching Grammar to Iranian EFL Learners } \\
\text { through Blended Learning Using Multimedia } \\
\text { Softwares. }\end{array}$ & $\begin{array}{l}\text { M. Aslani \& } \\
\text { H.H.Tabrizi }\end{array}$ & $\begin{array}{l}\text { Journal of Applied } \\
\text { Linguistics and Language } \\
\text { Research, 2015, 2(8), 76- } \\
87 .\end{array}$ \\
\hline
\end{tabular}




\begin{tabular}{|c|c|c|c|}
\hline 20 & $\begin{array}{l}\text { Drawing Up a Medical Syllabus by Integrating } \\
\text { the Gamified Blended Module of L } 2 \text { English } \\
\text { Learning }\end{array}$ & $\begin{array}{l}\text { S. Khazaie, \& H. } \\
\text { Vahid Dastjerdi }\end{array}$ & $\begin{array}{l}\text { Interdiscip J Virtual Learn } \\
\text { Med Sci. 2015, 6(4) }\end{array}$ \\
\hline 21 & $\begin{array}{l}\text { Vocabulary Instruction through Blended } \\
\text { Learning and Multimedia Software in Iranian } \\
\text { ESP Classes. }\end{array}$ & $\begin{array}{l}\text { M. H. Tahririan, } \\
\text {, S.Khalili \& S. } \\
\text { Bagheri }\end{array}$ & $\begin{array}{l}\text { Journal of English } \\
\text { Language Teaching and } \\
\text { Learning,2015, } 7(16), 37- \\
54 .\end{array}$ \\
\hline 22 & $\begin{array}{l}\text { Developing Blended learning in Iranian Banks: } \\
\text { a step up to quality improvement or } \\
\text { EscapeForm e-learning standards. }\end{array}$ & $\begin{array}{r}\text { Seraji. F., Safari. } \\
\mathrm{S}\end{array}$ & $\begin{array}{l}\text { Journal of Training \& } \\
\text { Development of Human } \\
\text { Resources,2015, 4(2), 17- } \\
38 .\end{array}$ \\
\hline 23 & $\begin{array}{l}\text { The comparison of the effectiveness of three } \\
\text { methods of direct instruction, computer-based } \\
\text { and the combined one on the reduction of } \\
\text { spelling problems of students with spelling } \\
\text { learning disorders }\end{array}$ & $\begin{array}{l}\text { A.Moloodi., B. } \\
\text { Karimi., Y. } \\
\text { Khorramabadi., } \\
\text { E. Soleimani }\end{array}$ & $\begin{array}{l}\text { Journal of Learning } \\
\text { Disabilities, } 2014,4(2) \text {, } \\
84-99 .\end{array}$ \\
\hline 24 & $\begin{array}{l}\text { Investigation of the differentiation of blended } \\
\text { learning with electronic learning and traditional } \\
\text { learning (face to face) in teaching mathematics }\end{array}$ & $\begin{array}{l}\text { G. Ahmadi., N. } \\
\text { Nakhostin Vahie }\end{array}$ & $\begin{array}{l}\text { Journal of school } \\
\text { psychology, } 2014,3(2) 6- \\
27\end{array}$ \\
\hline 25 & $\begin{array}{l}\text { Comparison effects of attendance, e-learning } \\
\text { and integrated leaning method on learning and } \\
\text { retention }\end{array}$ & $\begin{array}{l}\text { H. Magami., } \\
\text { E.Zaree., A. } \\
\text { 16Dellavar \& D. } \\
\text { Noroozi }\end{array}$ & $\begin{array}{l}\text { Journal of research in } \\
\text { educational systems, 2014, } \\
8(1), 17-39 .\end{array}$ \\
\hline 26 & $\begin{array}{l}\text { Comparing the Effectiveness of E-Learning, } \\
\text { Blended Learning and Face-to-Face Lecture in } \\
\text { Industrial Training. }\end{array}$ & $\begin{array}{l}\text { Z. Salari \& M. } \\
\text { Karami. }\end{array}$ & $\begin{array}{l}\text { New Educational } \\
\frac{\text { Approaches. } 2014,9(2)}{27.33}\end{array}$ \\
\hline 27 & $\begin{array}{l}\text { The effect of blended learning environment on } \\
\text { the satisfaction and training of industry } \\
\text { experts }\end{array}$ & $\begin{array}{l}\text { M. Karami \&Z. } \\
\text { Salari }\end{array}$ & $\begin{array}{l}\text { Journal of education } \\
\text { science, } 2014,20(2), 63- \\
80 .\end{array}$ \\
\hline 28 & $\begin{array}{l}\text { The Impact of Using Blended Learning on } \\
\text { Students' Creativity }\end{array}$ & $\begin{array}{l}\text { S. K. } \\
\text { Banihashem.,J. } \\
\text { Rezaei.,M. Badali } \\
\text { \&A. Dana }\end{array}$ & $\begin{array}{l}\text { Journal of Innovation and } \\
\text { Creativity in Humanities, } \\
2014,4(1), 113-128 .\end{array}$ \\
\hline 29 & $\begin{array}{l}\text { Comparing the effectiveness of designing the } \\
\text { blended learning environments with program- } \\
\text { based pedagogical theatre } \& \text { creative drama } \\
\text { method }\end{array}$ & $\begin{array}{l}\text { H. Moradi } \\
\text { Mokhles., M. } \\
\text { Mokhtabad., S. } \\
\text { Rashid }\end{array}$ & $\begin{array}{l}\text { Journal of Dramatic Arts } \\
\text { and Music, } 2014,7(4), 29- \\
40 .\end{array}$ \\
\hline 30 & $\begin{array}{l}\text { The effect of blended learning vs. classroom } \\
\text { learning techniques on Iranian EFL learners' } \\
\text { writing }\end{array}$ & $\begin{array}{l}\text { S. Ghahari \& A. } \\
\text { Ameri-Golestan }\end{array}$ & $\begin{array}{l}\text { International Journal of } \\
\text { Foreign Language Teaching } \\
\text { and Research,2014, 1, 1-9. }\end{array}$ \\
\hline 31 & $\begin{array}{l}\text { A Comparative Study of the Effects of Three } \\
\text { Blended Learning Scenarios in Promoting } \\
\text { Health Knowledge Level among Elementary } \\
\text { Students }\end{array}$ & $\begin{array}{l}\text { H. Mehdizadeh., } \\
\text { R. Fathi }\end{array}$ & $\begin{array}{l}\text { Journal of ICT in } \\
\text { Education, } 2013,3(3) \text {, } \\
113-127 .\end{array}$ \\
\hline
\end{tabular}




\begin{tabular}{|c|c|c|c|}
\hline 32 & $\begin{array}{l}\text { Application of Planning Blended Learning Based } \\
\text { on SWOT Pattern in Teaching-Learning } \\
\text { Activities of the Isfahan University of Medical } \\
\text { Science }\end{array}$ & $\begin{array}{l}\text { B. Zamani, H. } \\
\text { Babri }\end{array}$ & $\begin{array}{l}\text { Journal of Studies } \\
\text { Development of Medical } \\
\text { Science, } 2013,10(1), 95- \\
108 .\end{array}$ \\
\hline 33 & $\begin{array}{l}\text { Comparison Effectiveness of Blended Learning } \\
\text { with e-learning and attendance in Mathematics } \\
\text { Learning between the Girls and Boys. }\end{array}$ & A.Abdollahzadeh & $\begin{array}{l}\text { Journal of New Educational } \\
\text { Thoughts, } 2013,9(2), 65- \\
84 .\end{array}$ \\
\hline 34 & $\begin{array}{l}\text { Studying the Role of Students' Academic } \\
\text { Motivation and Computer Skills in Their } \\
\text { Attitudes toward Blended Learning Approach }\end{array}$ & A.Ajam et al & $\begin{array}{l}\text { Journal of new directions in } \\
\text { educational management, } \\
2013,15(4), 63-84 \text {. }\end{array}$ \\
\hline 35 & $\begin{array}{l}\text { A Blended Approach to Instructional Design } \\
\text { and Learning Environment: Critique of } \\
\text { Previous Models and Development of a New } \\
\text { Model }\end{array}$ & $\begin{array}{l}\text { E. Zare'i } \\
\text { Zuvarki }\end{array}$ & $\begin{array}{l}\text { Educational Psychology, } \\
2013,24(8), 29-50 .\end{array}$ \\
\hline 36 & $\begin{array}{l}\text { Hybrid learning and Iranian EFL learners' } \\
\text { autonomy in vocabulary learning. }\end{array}$ & I.E.Shams & $\begin{array}{l}\text { Procedia-Social and } \\
\text { Behavioral Sciences,2013, } \\
93,1587-1592 .\end{array}$ \\
\hline 37 & $\begin{array}{l}\text { Effect of integrated approach on learners } \\
\text { motivation and interest. }\end{array}$ & $\begin{array}{l}\text { E. Zareie } \\
\text { Zavaraki., M. } \\
\text { Azarnoosh., R. } \\
\text { Darvish }\end{array}$ & $\begin{array}{l}\text { Quarterly journal of } \\
\text { management on police } \\
\text { training, 2013,6(3), 51- } \\
66 .\end{array}$ \\
\hline 38 & $\begin{array}{l}\text { Studying the Role of Students' Academic } \\
\text { Motivation and Computer Skills in Their } \\
\text { Attitudes toward Blended Learning Approach }\end{array}$ & $\begin{array}{l}\text { A.Ajam., } \\
\text { H.Jafarisani., B. } \\
\text { Mahram \& M. } \\
\text { Ahanchian }\end{array}$ & $\begin{array}{l}\text { Journal of New Directions } \\
\text { in Educational } \\
\text { Management, 2013, 15(4), } \\
63-82 \text {. }\end{array}$ \\
\hline 39 & $\begin{array}{l}\text { A Comparison of the Effects of Blended } \\
\text { Learning and Lecture Based-Instruction on the } \\
\text { Students' Academic Motivation and Satisfaction }\end{array}$ & $\begin{array}{l}\text { F.Z. Naeemi ., H. } \\
\text { Hoseyni H. } \\
\text { Zare., M. } \\
\text { Hormozi \& M.H. } \\
\text { Kaveh }\end{array}$ & $\begin{array}{l}\text { Journal of Technology } \\
\text { Education, } 2012,3(2), 42- \\
50 .\end{array}$ \\
\hline 40 & $\begin{array}{l}\text { Designing and Implementing Blended Learning } \\
\text { in the Field of Rehabilitation }\end{array}$ & $\begin{array}{l}\text { M. Seyedi \& } \\
\text { Z.Yaghoubi }\end{array}$ & $\begin{array}{l}\text { research in Medical } \\
\text { Education, 2012,3(2), 42- } \\
50 .\end{array}$ \\
\hline 41 & $\begin{array}{l}\text { Advantages and Disadvantages of Blended } \\
\text { Teaching Method of Online and Face to Face } \\
\text { for Practical Course of Hematology the } \\
\text { viewpoint of Laboratory Science Students in } \\
\text { Mashhad University of Medical Science in } 2011\end{array}$ & $\begin{array}{l}\text { L. Manavifar\& J. } \\
\text { Jamali }\end{array}$ & $\begin{array}{l}\text { Iranian Journal of Medical } \\
\text { Education, } 2012,12(4) 619- \\
629 .\end{array}$ \\
\hline 42 & $\begin{array}{l}\text { The Role of Students' Self-regulated Learning } \\
\text { Strategies, Computer Skills and Academic } \\
\text { Achievement in Their Views about } \\
\text { Synchronous and Asynchronous Interactions in } \\
\text { Blended Combined Learning Approach }\end{array}$ & $\begin{array}{l}\text { A.Ajam.,H. } \\
\text { Jaafary Sani }\end{array}$ & $\begin{array}{l}\text { Journal of research in } \\
\text { curriculum planning, } 2012 \text {, } \\
7(2), 1-17 \text {. }\end{array}$ \\
\hline
\end{tabular}




\begin{tabular}{|c|c|c|c|}
\hline 43 & $\begin{array}{l}\text { Blended Learning a New Approach in } \\
\text { developing Teaching and Learning Process. }\end{array}$ & $\begin{array}{l}\text { E.Salehi Omran., } \\
\text { Z. Salari }\end{array}$ & $\begin{array}{l}\text { Journal of Educational } \\
\text { Strategy in Medical } \\
\text { Science, 2012, 5(1), 69- } \\
75 .\end{array}$ \\
\hline 44 & $\begin{array}{l}\text { Blended e-Learning: a new approach to } \\
\text { environmental education of Iran high schools }\end{array}$ & $\begin{array}{l}\text { S.Mazloumiyan,S } \\
\text { Shobeiri., M. } \\
\text { Farajollahi \& M. } \\
\text { Mohammadi }\end{array}$ & $\begin{array}{l}\text { Procedia-Social and } \\
\text { Behavioral Sciences,2012, } \\
47,1216-1220\end{array}$ \\
\hline 45 & $\begin{array}{l}\text { Blended learning: A ubiquitous learning } \\
\text { environment for reading comprehension. }\end{array}$ & $\begin{array}{l}\text { F. Behjat., M. } \\
\text { Yamini \& M.S. } \\
\text { Bagheri }\end{array}$ & $\begin{array}{l}\text { International Journal of } \\
\text { English } \\
\text { Linguistics,2012, 2(1), } 97 .\end{array}$ \\
\hline 46 & $\begin{array}{l}\text { An Analysis of the Preventive and Promoter } \\
\text { Factors of Applying Blended Learning System } \\
\text { in Agricultural Higher Education from the } \\
\text { Perception of Faculty Members of Khuzestan } \\
\text { Province's Faculties of Agriculture and Natural } \\
\text { Resources' }\end{array}$ & $\begin{array}{l}\text { A.Hashemi } \\
\text { Nezahd., S. } \\
\text { Mahmood } \\
\text { Hosseini \& Y. } \\
\text { Hejazi }\end{array}$ & $\begin{array}{l}\text { Iranian Journal of } \\
\text { Agricultural Economics and } \\
\text { Development Research, } \\
2012,43(3), 363-373 .\end{array}$ \\
\hline 47 & $\begin{array}{l}\text { Developing a Blended Course and investigating } \\
\text { its Psychological effect on Students. }\end{array}$ & $\begin{array}{l}\text { L. Mosalanejad., } \\
\text { A. Alipuor., B. } \\
\text { Zandi., H. } \\
\text { Zarea., M. Shiri }\end{array}$ & $\begin{array}{l}\text { Journal of Jahrom } \\
\text { University of Medical } \\
\text { Science, } 2010,8(1), 51-62 \text {. }\end{array}$ \\
\hline
\end{tabular}

Table 2. Lists of blended learning researches in Iran from new to old.

\section{a. Current status of blended learning researches in Iran}

Current status of Iranian blended learning researches was analyzed in six categories as follow:

\section{Application of the concepts and terminology of blended learning}

From among the 47 analyzed papers, 12 papers used the term "amoozesh-e tarkibi" [=blended instruction] (25.5 percent), 12 papers used "yadgiri-ye talfighi" [=integrated learning] (25.5 percent), 16 papers used "yadgiri-ye tarkibi" [=blended learning] (34.04 percent), 4 papers used "tadris-e ma'koos" [=reverse teaching] (8.51 percent), and the three terms "amoozesh-e talfighi" [=integrated instruction], "tadris-e tarkibi" [=blended teaching], and "poodman-e tarkibi" [=blended package] were each used only once (2.1 percent).

\section{Blended learning Methodology}

The dominant methodology of blended learning research in Iran has focused on quantitative methods. In our sample, 38 studies used quantitative methodology ( 80.85 percent), 7 studies used qualitative methodology (14.89 percent), and 2 studies used mix methods approach (4.25 percent). Furthermore, 31 studies used quasi-experimental method (65.95 percent), 5 studies were reviews (10.63 percent), 4 studies were surveys ( 8.51 percent), 4 studies used causalcomparative method (6.38 percent), 2 studies used exploratory method (4.25), and one study used a combination of methods (2.12 percent). In general, 57 tools were used for data collection 
which consisted of 36 questionnaires (63.15 percent), 14 tests (24.56), 6 instances of note-taking (10.52 percent), 3 interviews ( 5.26 percent), one instance of narrative (3.50 percent), and one instance of observation ( 3.50 percent).

\section{Introduced features of blended learning}

Blended learning and its related notions were distinguished by combination of the features of physical and virtual environments in 21 studies (44.68 percent), by use of computers in education in 16 studies (34.04 percent), by reversed teaching in 9 studies (19.14 percent), and by multimodal and flexible combinations in one study ( 2.12 percent). From among the 47 papers, 16 studies made use of a computer application in the physical classroom to realize the idea of blended learning. 5 studies were reviews of the fundamentals and features of blended learning and 2 studies contained a survey of the opinions of teachers, students, and university lecturers. The ten aspects of blended learning were addressed as following in 20 studies: Policy-making, planning, and support were addressed in one study, time scheduling in one study, coordination in 2 studies, use of system in 6 studies, flexibility in 17 studies, interaction in 16 studies, creation of an atmosphere of active learning in 11 studies, and facilitation of the learning process in 8 studies. In a descending order of importance, therefore, the treatment of the ten aspects of blended learning is as following: flexibility (17 papers), interaction (16), creation of an atmosphere of active learning (11), facilitation of the learning process and use of system (8), coordination (2), policy-making (1), planning (1), support (1), and time scheduling (1).

\section{Level of blended learning}

Blended learning is classified at activity, course, program and organizational levels. 37 studies were at course level (78.72 percent), 3 studies at are in activity level (6.38 percent), one study is at organizational level (2.12 percent), and 6 studies are at no specific level (12.76 percent).

\section{Related Variables that studied}

From among the 57 variables in question, 44.18 percent addressed learning and retaining, 13.95 percent addressed learner's characteristics, 9.30 percent addressed educational motivation, 6.97 percent addressed computer skills, 4.65 percent addressed professional development and educational satisfaction, and 2.32 percent addressed critical thinking, self-efficacy, educational involvement, creativity, interest, facilitating and inhibiting factors, and various forms of intelligence.

\section{Educational program under study}

From among the 47 studies, 46.15 percent addressed higher education, 23.07 percent addressed high school, 12.82 percent addressed primary school and kindergarten, 7.69 percent addressed organizational training, and 10.25 addressed blended learning without focusing on a specific program.

\section{Discussion and Criticisms}

In this section, eleven criticisms are raised on the basis of the six basic categories discussed above. With regard to the use of terminology, two criticisms can be levelled. In the papers analyzed here, the notion of blended learning is referred to by seven terms, i.e. "amoozesh-e tarkibi" [=blended 
instruction], "yadgiri-ye talfighi" [=integrated learning], "yadgiri-ye tarkibi" [=blended learning], "tadris-e ma'koos" [=reversed teaching], "amoozesh-e talfighi" [=integrated instruction], "tadris-e tarkibi" [=blended teaching], and "poodman-e tarkibi" [=blended instructional package]. Some these terms have already been present in the educational literature. The first issue to taken is that Iranian studies make use of only a handful of terms whereas international literature uses a variety of terms such as blended teaching, learning with blended pedagogies, blended learning, hybrid learning, dual-mode university, brick-and-click university, targeted blending, multimodal learning, HyFlex learning (highly flexible learning), rotational learning, and reverse learning to refer to different aspects and features of blended learning.

The second criticism that can be raised here is that some studies use the notions of blended learning and integrated learning interchangeably. In the literature on educational curricula, however, the term "integration" refers to a curriculum which eliminates discipline boundaries and provides learning experiences beyond these boundaries. This notion has been in use since the 1950 s in the field of curriculum and instruction. Thus, concepts such as integrated teaching and learning cannot be taken as an equivalent to blended learning. Other terms such as reverse teaching, inverted class, and blended package conform to the mainstream terminology of the international literature.

As with the methodology, three criticisms are to be raised. It is unfortunate that in many branches of education such as e-learning, qualitative methodology and mix methods approach are much more common (Johnson \& Daugherty, 2008; Arbaugh, Desai, Rau \& Sridhar, 2010 ; Dziuban \& Picciano, 2015 ) while the dominant methodology in Iranian studies of blended learning is still quantitative. Another criticism should be leveled at the application of quasi-experimental designs. In a quasi-experimental study, control of some intervening variables may cause the learning environment to appear artificial and inauthentic. In a well-implemented blended learning environment, the various variables of the physical and virtual environments are difficult to control for the researcher. Therefore, excessive use of quasi-experimental methods may lead to inappropriate design and implementation of blended learning programs.

The next criticism addresses the lack of case studies. A common, efficient method to promote educational innovations is to record the personal narratives of learners who have experienced blended learning, practitioners, decision-makers, and implementers. However, there was no case study among the analyzed papers. This may indicate that no educational organization in Iran has officially implemented blended learning environments. Seraji and Safari (2015) point out that banks offer part of their educational services in physical form and part of in electronic form. However, it seems that this is not intended to improve learning quality but to evade the demands of e-learning such as production of electronic contents.

The definition and characterization of blended learning in Iranian studies can be criticized from two aspects. In 34.04 percent of the studies, integration of technology, software applications, or multimedia contents into physical learning is considered as equal to blended learning. In the rest of the studies, the ten features of blended learning are neglected. It should be noted that the idea of blended learning was developed in 2000 to refer to optimal combination of the features of physical and virtual environments on the basis of pedagogies and learning theories and with the aim of contributing to learning objectives. Mere use of technologies such as computers, software applications, and multimedia materials, however, have been referred to as computer-aided instruction, computer-supported instruction, multimedia learning, and similar terms, especially after the invention of Skinner's teaching machine. Iranian studies have not been able to distinguish between blended learning and computer-aided learning. As another criticism, it can be said that these studies have usually limited blended learning to a simple combination of physical and virtual environments. In the 20 studies which attempted to characterize blended learning, one study addresses policy-making, planning, support services, and time scheduling, 2 studies address 
coordination, 6 studies address learning management system, 17 studies address flexibility, 16 studies address interaction, 11 studies address creation of an atmosphere of active learning, and 8 studies address facilitation of the learning process. As the third wave of learning environments, blended learning environments require policies, strategies, plans, schedules, and coordination of resources so that, in line with specific organizational policies, resources and features of physical and virtual environments can be combined in a coordinated, planned manner according to the synchronous and asynchronous conditions of the learner in order to improve the quality of learning.

On the other hand, it would be impossible to assume blended learning without a learning management system. A learning management system is a tool for managing access to contents, sending and receiving learning activities, participating in synchronous and asynchronous discussions, participating in constant self-assessments, creating reports of the activities of the learner, etc. Along these actions, physical interaction, support, teaching, and assessment should also be possible. Although 6 studies mention learning management system or specific software for management of teaching, none of the studies address all ten features of blended learning. As a result, educational organizations usually do not tend to provide plans for the development of blended learning environments at the policy-making level. At a practical level, however, some teachers design and implement such plans on their own, which are likely to be seriously deficient in terms of collective aims, coordination among resources, support, scheduling, and preparation of the system. In their study of the design and policy-making of blended learning in six American universities, Graham et al (2013) discovered that some universities are lacking specific policies and structures for the development of blended learning and they are still in the stage of searching and seeking knowledge. Some universities are in the stage of acceptance and initial implementation. These universities have recognized their aims and policies for the development of blended learning but do not have a specific schedule for enhancing interaction, flexibility, and support of the learning process. The third group consists of universities that are in an advanced stage of acceptance and have exactly defined aims, policies, support, and motivational mechanisms for the development of blended learning. According to their findings, three universities are in the stage of searching and seeking knowledge, two are in the stage of initial acceptance, and only one major university has reached a mature state.

Enhancement of interaction and flexibility of the educational programs is an important feature of a blended learning environment that is expected to promote active learning and facilitate the learning process. However, only 8 studies address flexibility and only 11 studies address enhancement of synchronous and asynchronous physical and virtual interactions. This is in contrast to the emphasis of Bowlens et al (2017) on the fact that interaction and flexibility are essential to the blended learning environment.

The next criticism addresses levels of learning. The majority of the analyzed studies deal with blended environment at the level of educational program. Although Bowlens et al (2017) show that this has also been the case in the international literature, Graham et al (2013) emphasize that development of blended learning requires macro-level long-term decisions, policies, plans, coordination, and support at an organizational level, which is a large gap in the Iranian blended learning research and practice.

In addition, some of the variables of blended learning have been mostly neglected in Iranian research. From among the 57 variables investigated, the most widely studied ones were learning and retaining, learner's characteristics, educational motivation, computer skills, professional development, and educational satisfaction. Some important, but neglected, issues include methods of policy-making, planning for blended learning, method of support, perspectives of the development of blended learning, integration of flexibility into blended programs according to the conditions of time, place, content, learning activities, tools, technologies, teaching methods, learning resources as well as assessment methods, methods of creating research communities, 
reinforcement of cognitive, social, and instructional presence, personal self-learning, and guided self-learning. Two criticisms are of importance here. First, researches have only focused on the study of learning and retention. However, quality of learning should not be confined to assessment scores and retention of learned materials, but it also covers depth of learning, learner's motivation, enhancement of learner's interaction and participation, cognitive, social, and instructional presence, and gaining qualifications at higher cognitive and emotional levels, which are far more important than educational scores. Second, variables of policy-making and macro-level organizational decision-making have been largely neglected. Only one of the studies addresses decision-making, policy-making, and development of blended programs. This is indicative of insufficient attention to the positive effect of these large-scale issues on the development of blended learning.

Finally, blended learning is widely used for higher education and organizational as well as professional training programs around the world. This is why Rose and Gage (2006) refer to it as the new tradition of academic education. Development of blended learning is not as much important in public education programs. Integration of technology into primary and secondary education has been usually addressed in projects such as School Net, School+, smart school, and virtual schools. Therefore, the term blended learning is not usually applied to public educational environments such as primary and secondary schools.

\begin{tabular}{|c|c|}
\hline Category & Criticisms \\
\hline \multirow[t]{2}{*}{$\begin{array}{l}\text { Application of } \\
\text { terminology }\end{array}$} & $\begin{array}{l}\text { Criticism 1: Limited terminology in comparison with the variety of terms in } \\
\text { the international literature that describe the different situations of blended } \\
\text { learning }\end{array}$ \\
\hline & Criticism 2: Use of inappropriate terms \\
\hline \multirow{3}{*}{ Methodology } & Criticism 3: Dominance of quantitative methodology \\
\hline & Criticism 4: Excessive use of quasi-experimental design \\
\hline & Criticism 5: Lack of case studies \\
\hline \multirow{2}{*}{$\begin{array}{l}\text { Definition and } \\
\text { characterization of } \\
\text { blended learning }\end{array}$} & $\begin{array}{l}\text { Criticism 6: Confusing the notion of blended learning with other applications } \\
\text { of computer technology or virtual environments in education }\end{array}$ \\
\hline & $\begin{array}{l}\text { Criticism 7: Overemphasis on simple combination of physical and virtual } \\
\text { environments instead of addressing the authentic characteristics of blended } \\
\text { learning environments }\end{array}$ \\
\hline $\begin{array}{l}\text { Levels of blended } \\
\text { learning }\end{array}$ & $\begin{array}{l}\text { Criticism 8: Excessive focus of research on the level of educational programs } \\
\text { and lack of attention to the levels of activity, curriculum, and organization }\end{array}$ \\
\hline \multirow{2}{*}{$\begin{array}{l}\text { Variables of the } \\
\text { study }\end{array}$} & Criticism 9: Superficial emphasis on learning and retention \\
\hline & Criticism 10: Lack of attention to some variables of blended learning \\
\hline $\begin{array}{l}\text { Educational } \\
\text { programs }\end{array}$ & $\begin{array}{l}\text { Criticism 11: Blended learning is widely used in universities and } \\
\text { organizational environments. In general education programs, other terms } \\
\text { are preferred to refer to the integration of technology. }\end{array}$ \\
\hline
\end{tabular}

Table 3: Criticisms leveled at blended learning research in the Iranian context. 


\section{Conclusion}

As the third wave of learning environments, the notion of blended learning environment followed physical and virtual environments. Such an environment is developed on the basis of educational, pragmatic, holistic, and organizational perspectives. The educational perspective requires efficient use of the features of both physical and virtual environments. From a pragmatic perspective, the focus is on the solving of the problems of the physical or virtual learning environment. The organizational perspective emphasizes organizational aims and missions. Finally, the holistic perspective addresses the potential of physical and virtual environments to facilitate the realization of the aims of learning and solve the its problems. By using these perspectives to design learning environments, enhancement of elements such as self-paced learning, live events, participation, assessment, and support of performance becomes possible. However, what distinguishes blended learning from other concepts like web-based education, virtual education, e-learning, computeraided education, computer-based education, and similar terms is not the mere combination of physical and virtual environments but the fact that this combination must be based on specific plans and policies and aim at realizing those objectives that physical and virtual environments alone are not able to achieve. Thus, in a combination of physical and virtual environments, elements such as technologies, time, place, roles, pedagogies, educational aims, and independence and support of the learner should be blended in a way that, while maintaining and reinforcing the motivations for learning, they provide an appropriate environment for learner's self-directed, independence, reflection, interaction, participation, self-assessment, and participation. Nevertheless, lack of objective criteria and overlapping with other similar concepts has caused the notion of blended learning to be misunderstood by many researchers.

The notion of blended learning came to vogue in Iran in 2010. The present study sought to identify how blended learning is represented in Iranian researches as well as to review those studies. The six categories of studying blended learning and the eleven criticisms raised in this study show that researchers, designers, and implementers of the integration of technology into curriculum and instruction do not possess an accurate understanding of this type of learning and usually consider it as equal to a simple combination of physical and virtual environments or, sometimes, to using computer software in physical learning environments. In addition, lack of case studies and excessive use of quasi-experimental design indicate that Iranian educational organizations have not yet come to use blended learning in the real sense. In conclusion, it can be inferred that the general conception of blended learning in the Iranian context is not in agreement with the four groups of research trends discussed above, namely, categorization of the notions related to blended learning, specification of the continuum of different combinations of physical and virtual environments, focus on the implications of combination of physical and virtual environments, and the four levels of the development of blended learning.

\section{References}

Allen, I. E., Seaman, J., \& Garrett, R. (2007). Blending in: The extent and promise of blended education in the United States. Sloan Consortium. PO Box 1238, Newburyport, MA 01950.

Antonoglou, L. D., Charistos, N. D., \& Sigalas, M. P. (2011). Design, development and implementation of a technology enhanced hybrid course on molecular symmetry: Students' outcomes and attitudes. Chemistry Education Research and Practice, 12(4), 454-468. http://doi.org/10.1039/C0RP90013C

Arbaugh, J. B., Desai, A., Rau, B., \& Sridhar, B. S. (2010). A review of research on online and blended learning in the management disciplines: 1994-2009. Organization Management Journal, 7(1), 39-55.

Arispe, K., \& Blake, R. J. (2012). Individual factors and successful learning in a hybrid course. System, 40(4), 449-465. http://dx.doi.org/10.1016/j.system.2012.10.013. 
Bleed, R. (2001). A hybrid campus for the new millennium. EDUCAUSE Review, 36(1), 16-24. Retrieved from https://net.educause.edu/ir/library/pdf/erm0110.pdf.

Boelens, R., De Wever, B., \& Voet, M. (2017). Four key challenges to the design of blended learning: A systematic literature review. Educational Research Review, 22(4), 1-18. doi:https://doi.org/10.1016/j.edurev.2017.06.001.

Carman, J. M. (2005). Blended Learning Design: Five Key Ingredients. Blended Learning Design: 5 Key Ingredients, 1-10. Retrieved from http://www.agilantlearning.com/pdf/Blended Learning Design.pdf.

Cuesta. M. L. (2018). Blended learning: Deficits and prospects in higher education. Australasian Journal of Educational Technology, 34(1), 42-56. https://doi.org/10.14742/ajet.3100

Dziuban, C., \& Picciano, A. (2015). The evolution continues. ECAR Research, 6(15), 1-19.Available from http://www.educause.edu/ecar.

Graham, C. R., Woodfield, W., \& Harrison, J. B. (2013). A framework for institutional adoption and implementation of blended learning in higher education. The internet and higher education, 18, 4-14. doi: $10.1016 / j$.iheduc.2012.09.003.

Gedik, N., Kiraz, E., \& Ozden, M. Y. (2013). Design of a blended learning environment: Considerations and implementation issues. Australasian Journal of Educational Technology. 29(1),1-19.

Kyei-Blankson, L. \& Godwyll, F. (2010). An Examination of Learning Outcomes in Hyflex Learning Environments. In J. Sanchez \& K. Zhang (Eds.), Proceedings of E-Learn 2010--World Conference on ELearning in Corporate, Government, Healthcare, and Higher Education (pp. 532-535). Orlando, Florida, USA: Association for the Advancement of Computing in Education (AACE). Retrieved August 4, 2018 from https://www.learntechlib.org/primary/p/35598/.

Johnson, J. V., Abia, M., \& Quest, R. (2016, January). A comparison of blended and traditional approaches to computing and informatics instruction in Namibia Outcomes and consequences for a developing nation. In International Conference on Computer Science Education Innovation \& Technology (CSEIT). Proceedings (p. 111). Global Science and Technology Forum.

Johnson, S.D \& Daugherty. J (2008). Quality and Characteristics of Recent Research in Technology Education. Journal of Technology Education. 20(1).16- 31.

Margulieux, L. E., Bujak, K. R., McCracken, W. M., \& Majerich, D. M. (2014, January). Hybrid, blended, flipped, and inverted: Defining terms in a two dimensional taxonomy. In Paper accepted to the 12th Annual Hawaii International Conference on Education. Honolulu, HIJanuary (Vol. 2014, pp. 5-9).

Moskal, P., Dziuban, C., \& Hartman, J. (2013). Blended learning: A dangerous idea? The Internet and Higher Education, 18(2), 15-23. http://doi.org/10.1016/j.iheduc.2012.12.001

Moore, M. G., \& Kearsley, G. (2011). Distance education: A systems view of online learning. Cengage Learning: USA.

Oliver, M., \& Trigwell, K. (2005). Can 'blended learning 'be redeemed? E-learning and Digital Media, 2(1), 1726.

Ochoa, G., Hyde, M., Curtois, T., Vazquez-Rodriguez, J. A., Walker, J., Gendreau, M., \& Burke, E. K. (2012, April). Hyflex: A benchmark framework for cross-domain heuristic search. In European Conference on Evolutionary Computation in Combinatorial Optimization (pp. 136-147). Springer, Berlin, Heidelberg.

Picciano, A. G. (2009). Blending with purpose: The multimodal model. Journal of the Research Center for Educational Technology, 5(1), 4-14.

Ross, B., \& Gage, K. (2006). Global perspectives on blending learning. BonkJ. C. GrahamR. C.(Eds.), The handbook of blended learning, 155-168.

Sands, P. (2002). Inside outside, upside downside: Strategies for connecting online and face-to-face instruction in hybrid courses. Teaching with Technology Today, 8(6), 12-23. Retrieved from http://www.uwsa.edu/ttt/articles/sands2.htm. 
Seraji. F., Safari. S (2015). Developing Blended learning in Iranian Banks: a step up to quality improvement or Escape Form e-learning standards. Journal of Training \& Development of Human Resources,2015, 4(2), 1738.

Sloan Consortium. (2007). blending in: The extent and promise of blended education in the United States. Retrieved from http://olc.onlinelearningconsortium.org/publications/survey/blended06.

Stoffberg, E. M., \& Blignaut, A. S. (2008). A case for multimodal training of electronic databases at a higher education institution. South African journal of libraries and information science, 74(1), 1-8.

Turner, F., \& Crews, J. (2005). Bricks and clicks: A comparative analysis of online and traditional education settings. International Journal of Instructional Technology and Distance Learning, 2(4), 3-8 